\title{
Effect of water quality on the feeding ecology of axolotl Ambystoma mexicanum
}

\author{
Diego de Jesus CHAPARRO-HERRERA, ${ }^{2}$ Sarma NANDINI, ${ }^{1 *}$ S.S.S. SARMA ${ }^{1}$ \\ ${ }^{1}$ Laboratorio de Zoología Acuática, División de Investigación y Posgrado, Universidad Nacional Autónoma de México, Campus \\ Iztacala, Avenida de los Barrios S/N, 54090 Tlalnepantla; ${ }^{2}$ Universidad Nacional Autónoma de México, Ciudad Universitaria, \\ 04510 Mexico City, Mexico \\ *Corresponding author: nandini@unam.mx
}

\begin{abstract}
Ambystoma mexicanum, a highly endangered species, is endemic to lake Xochimilco (Mexico City, Mexico) which currently is being negatively affected by the introduction of Oreochromis niloticus (Tilapia) and water pollution. During the first weeks of development, when mortality is the highest, Ambystoma mexicanum depends on a diet of zooplankton. The aim of this study was to check whether contamination levels in lake Xochimilco influence zooplankton consumption by similar size classes of A. mexicanum and Oreochromis niloticus. In this study, we analysed changes in the functional responses and prey preference of A. mexicanum and larval Tilapia in two media, one with filtered lake Xochimilco water and another one with reconstituted water. As prey we used cladocerans (Moina macrocopa, Alona glabra, Macrothrix triserialis and Simocephalus vetulus) and ostracods (Heterocypris incongruens). Zooplankton was offered in 5 different densities, 10, 20, 40, 80, 160 ind./mL. Prey consumption by A. mexicanum varied in relation to the species offered and age of the larvae. From the first week to the eighth week prey consumption by A. mexicanum increased by 57\%. Our functional response tests showed that regardless of the prey type, prey consumption by A. mexicanum was lower in the contaminated water from lake Xochimilco. Among the zooplankton offered in the contaminated environment predators preferred smaller and slower moving microcrustaceans such as Alona glabra and Heterocypris incongruens. Furthermore, O. niloticus preferred prey such as Moina macrocopa and Macrothrix triserialis in the contaminated medium and was more voracious than the axolotl. Our results indicate that both water quality of the lake and the presence of the more resistant exotic fish adversely impact the survival of this endangered amphibian.
\end{abstract}

Key words: Ambystoma mexicanum, Oreochromis niloticus, invasive species, zooplankton, water pollution.

Received: Janaury 2013. Accepted: April 2013.

\section{INTRODUCTION}

Amphibians including axolotls are usually adversely affected by anthropogenic influences (Alford and Richards, 1999; Blaustein and Bancroft, 2007). Pollution and climate change are among the main factors that contribute to the loss of amphibian taxa globally (Rahel and Olden, 2008; Sinervo et al., 2010). The consequences of pollution in ecological processes of amphibians are almost never evident. While the direct effects of pollution on growth and reproduction are easily measured, the more subtle effects on behaviour often are undocumented. For example, concentrations of nitrate-nitrogen at $3 \mathrm{mg} \mathrm{L}^{-1}$ for $96 \mathrm{~h}$ affect food consumption and mobility, resulting in severe weight loss and high mortality of amphibians (Rouse et al., 1999). Raimondo et al. (1998) have found that the predatory activity decreases in larval amphibians (Rana catesbeiana) exposed to heavy metals. Currently, underwater aquatic ecosystems are strongly affected by pollution (Mahaney, 1994; Lefcort et al., 1997), anthropogenically caused as a result of industry, agriculture and the introduction of alien species.

There are 31 species in the genus Ambystoma, of which 21 species are distributed in different habitats in Mexico.
Ambystoma mexicanum is critically endangered, with very sparse populations in its native habitat, lake Xochimilco in Mexico City (www.iucnredlist.org) (Fig. 1). Ambystoma mexicanum is a neotenic amphibian measuring $25-30 \mathrm{~cm}$ when adult. These amphibians are mostly detritivores but adults can also feed on fish. Cannibalism has been observed in crowded colonies but is not often seen in nature (Wells, 2007). Since eggs are often deposited on the substrate, they suffer the adverse effects of exposure to pollutants from an early stage. In the developing embryonic stages $A$. mexicanum can be altered when embryos are exposed to contaminants through their uptake from the environment (Werner, 1986; Higginson and Ruxton, 2010).

Changes in feeding behaviour can be attributed to several aspects, such as changes in sensory abilities since it is known that contaminants (heavy metals) may interfere with the smell of aquatic organisms (Hara, 1982). Indirect effects are often more influential in the feeding ecology of species, even when direct effects are quantified indirect effects may result in unforeseen competitive interactions (Miller and Kerfoot, 1987). The contaminants or toxic substances may have important indirect effects on organisms with relation to their ecological settings, even if the direct effects are weak or undetectable (Lefcort et al., 
1997; Pratt et al., 1997; Bridges and Semlitsch, 2000). One of the potentially important effects of pollution is its influence on habitat changes (Treherne and Foster, 1981; Petranka et al., 1987). Small amounts of contaminants that do not cause serious physiological effects may interfere with the food chain and thereby alter predator-prey and competitive interactions between prey species (Johnson et al., 2012). Therefore, sub-lethal direct effects may be important in a cascade of indirect consequences.

Many lakes of central Mexico are contaminated as is the case of lake Xochimilco, the endemic habitat of the amphibian A. mexicanum (Smith and Smith, 1971). Water quality in the canals of the lake system is of poor quality because they are fed by partly treated wastewater, containing a large amount of inorganic and organic chemicals such as salts, heavy metals, essential-oil, fats, oils and industrial solvents (Carey and Bryant, 1995; Thomson et al., 1999; Karraker et al., 2008). Although contaminated, this system contains a few populations of amphibians (Ambystoma mexicanum), insects and fish (predators), mainly zooplankton and insect prey (Chaparro-Herrera et al., 2011).

The replacement of a native predator by an exotic species may lead to changes in the structure of the community as a result of predation (Townsend, 2003), indirectly through the food interactions between prey (Hobbs and Huenneke, 1992; Kiesecker and Blaustein, 1998) or both (Beisner et al., 2003). In recent years several invasive taxa have been recorded in Mexico. Tilapia (Oreochromis sp.) is among the most pernicious predators in aquatic systems and is now found commonly in a large majority of water bodies in Mexico (Zambrano et al., 2010). Our previous observations indicate that $A$. mexicanum is a slow feeding species and thus could suffer in the presence of active predators such as Tilapia (Zambrano et al., 2010).

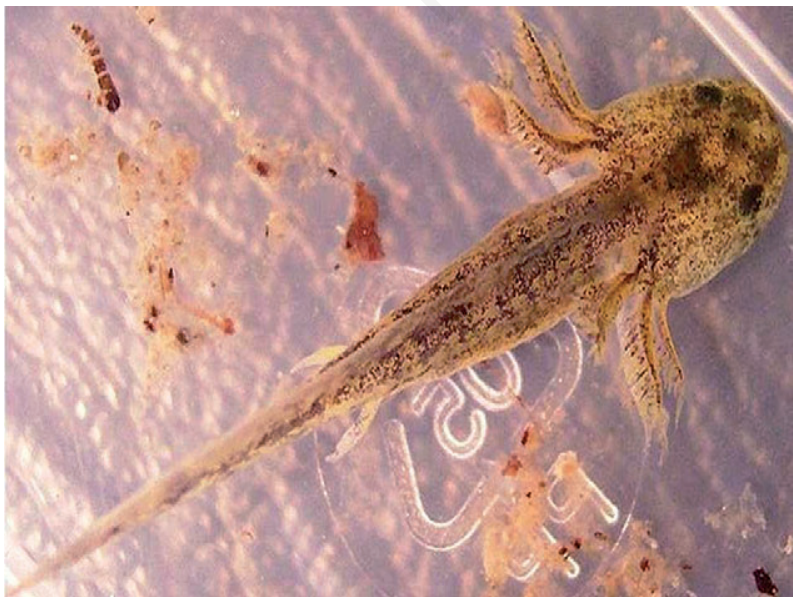

Fig. 1. Larva of Ambystoma mexicanum in the $4^{\text {th }}$ week of development.
While there is extensive literature on the toxic effects of pollutants on amphibian larvae, data to determine longterm effects on the dynamics of amphibian populations are fragmentary (Alford and Richards, 1999). Therefore, in this study we determined the effects of the (polluted) water present in the canals of Xochimilco through ex-situ experiments on food preference and functional response of larvae of A. mexicanum. We also conducted prey preference experiments on the invasive Oreochromic niloticus in order to compare its sensitivity under conditions similar to those for the endemic amphibian A. mexicanum in lake Xochimilco (Dominguez-Dominguez et al., 2002, Chaparro-Herrera et al., 2011; ).

\section{METHODS}

\section{Maintenance of Ambystoma mexicanum}

Fertilised eggs (about 400 per breeding pair) of $A$. mexicanum were obtained from the Laboratory of Herpetology of the Faculty of Higher Studies Iztacala (National Autonomous University of Mexico), and were incubated at 15 to $18^{\circ} \mathrm{C}$ one photoperiod 12:12h L:D. The parents of the offspring of $A$. mexicanum had been kept under laboratory conditions for the previous ten years. It was impossible to get breeding pairs in the wild for two reasons: i) A. mexicanum is a protected species, and therefore it is not allowed to capture animals from lake Xochimilco; and ii) the density of population in the wild is less than 0.01 ind. $\mathrm{m}^{-2}$ (Chaparro-Herrera et al., 2011).

Of the approximately 400 eggs oviposited, around $75 \%$ hatched, but $40 \%$ of the hatched larvae died during the second week. The remaining individuals survived until the end of study period. Larvae were maintained in moderately hard water [Environmental Protection Agency (EPA) medium], which was prepared by dissolving 0.095 $\mathrm{g}$ of $\mathrm{NaHCO}_{3}, 0.06 \mathrm{~g}$ of $\mathrm{CaSO}_{4}, 0.06 \mathrm{~g}$ of $\mathrm{MgSO}_{4}$, and $0.002 \mathrm{~g} \mathrm{KCl}$ in $1 \mathrm{~L}$ of distilled water (EPA, 1985). Our observations indicate that hard water prevents the growth of fungus on the skin of the larvae of A. mexicanum. The use of culture medium for the predator and prey also helped to avoid stress during the experiments. The larvae were maintained in shallow transparent trays, and were fed ad libitum with a mixture of rotifers and cladocerans, before and after the experiments.

\section{Maintenance of the larval fish Oreochromis niloticus}

We obtained 400 newly hatched larvae from the laboratory of Aquaculture Environmental Education Center Acuexcomat, Mexico City. The larvae were maintained at room temperature of $18-22^{\circ} \mathrm{C}$ over a photoperiod of $12: 12$ $\mathrm{h} L$ :D. These organisms had been maintained in laboratory conditions for the previous 5 years but $10 \%$ of the larvae died during the first week. The remaining individuals survived until the study period ended. Larvae were 
maintained in the EPA medium. The other test conditions were similar to those described above.

\section{Maintenance of zooplankton for food and experiments}

The size of the prey and the locations where they were isolated are shown in Tab. 1. All zooplankton prey used in this study were grown using EPA medium and microalgae Chlorella vulgaris and Scenedesmus acutus (at a density of 0.5 to $1.0 \times 10^{6}$ cells $\mathrm{mL}^{-1}$, respectively) as food. Micro-algal species were grown separately in batches using Bold Basal medium supplemented with sodium bicarbonate (Borowitzka and Borowiztka, 1988). The microalgae were harvested in the exponential phase of their growth, centrifuging at $3000 \mathrm{rpm}$ for $5 \mathrm{~min}$; later they were rinsed and re-suspended in a small amount of distilled water. The micro-algal density was enumerated using a Neubauer hemocytometer.

\section{Prey preference experiments}

Experiments on prey preference were conducted in the laboratory every week for the first eight weeks. Experiments were carried out weekly to analyse the impact of water quality of lake Xochimilco on the preference and consumption of zooplankton by $A$. mexicanum and $O$. niloticus. We used freshly collected water from the lake which was to observe the effects of food quality on the ecology, and the water was filtered through a mesh of 20 $\mu \mathrm{m}$. A. mexicanum or fish larvae were placed in clean water without food for $2 \mathrm{~h}$ prior to the experiments. The number of prey ingested was determined based on differences between the density of initial and final prey (Dominguez-Dominguez et al., 2002). Zooplankton offered in preference experiments were cladocerans (Moina macrocopa, Alona glabra, Macrothrix triserialis and Simocephalus vetulus) and ostracods (Heterocypris incongruens). Consumption was estimated for each species based on the zooplankton left in the experimental vessels. Experiments were conducted in containers of 300 $\mathrm{mL}$ capacity, with the EPA medium as a control and with the filtered lake water. Three treatments were set up: i) food preference of $A$. mexicanum alone: two larvae were placed in $100 \mathrm{~mL}$ with 50 individuals of each prey; ii) food preference of $O$. niloticus: two larvae were placed in $100 \mathrm{~mL}$ of medium with 50 individuals of each prey; and iii) food preference of $A$. mexicanum and $O$. niloticus together: two larvae of each predator were placed together in $200 \mathrm{~mL}$ of medium with 100 individuals of each prey. We added two larvae per container in order to ensure adequate consumption of prey (Gliwicz and Wrzosek, 2008), and at the end of the experiment, prey consumption was expressed per larva. For each treatment, four replicates were set up. Manly's $\alpha$ was calculated for all the experiments. This index is derived on the basis of number of prey consumed in relation to that offered. Values of $\alpha$ greater than $1 / \mathrm{m}$ - where $\mathrm{m}$ is the number of prey species offered - indicates preference, less than $1 / \mathrm{m}$ indicates avoidance, and values same as $1 / \mathrm{m}$ indicate neither selection nor avoidance (Krebs, 1999).

\section{Functional response experiments}

Functional response behaviour on two different prey (M. macrocopa and $H$. incongruens) of $A$. mexicanum was compared in EPA medium and water from lake Xochimilco. The functional response experiments were performed every week for the first eight weeks after hatching, at five prey densities for the two diets (M. macrocopa and H. incongruens: 10, 20, 40, 80 and 160 ind $\mathrm{mL}^{-1}$ ) with four replicates (Chaparro-Herrera et al., 2011). Adult zooplankton was used in the experiments. The media were placed in containers of $200 \mathrm{~mL}$ with $50 \mathrm{~mL}$ medium. We added the prey at the desired density to each container. Pre-starved larvae were added to the vessel. Experiments were conducted in diffuse fluorescent illumination at a temperature of $18 \pm 2^{\circ} \mathrm{C}$. Axolotls were fed for a period of $1 \mathrm{~h}$. Prey consumption was estimated based on the difference in initial and final prey density. The data were transformed using Michaelis-Menten constant where the line is a hyperbola similar to the consumption of $A$. mexicanum. We tested statistical differences in prey consumption using 3-way ANOVA.

\section{RESULTS}

In the analysis of preferences, microcrustaceans were used as prey. All these prey taxa coexist in lake Xochi-

Tab. 1. Microcrustaceans used in the experiments and location where taxa were obtained.

\begin{tabular}{lcc}
\hline Species & Length $(\mu \mathrm{m})(\mathrm{mean} \pm \mathrm{SE})$ & Localities \\
\hline Alona glabra & $430 \pm 2$ & Lake Chapultepec, Mexico City \\
Macrothrix triserialis & $770 \pm 15$ & Pond in Veracruz, Veracruz \\
Moina macrocopa & $1310 \pm 20$ & Manuel Avila Camacho reservoir, Puebla \\
Simocephalus vetulus & $2100 \pm 15$ & Pond in Veracruz, Veracruz \\
Heterocypris incongruens & $930 \pm 13$ & Pond in Guanajuato, Guanajuato \\
\hline
\end{tabular}

SE, standard error. 
milco with $A$. mexicanum. The prey sizes ranged from 430 to $2100 \mathrm{~mm}$ (Tab. 1).

The behaviour of $A$. mexicanum and $O$. niloticus in terms of preference for microcrustacean diet offered over eight weeks showed distinct differences depending on the two different media, contaminated water (lake Xochimilco), or EPA medium (Fig. 2). In the first week, A. mexicanum manifested a low preference for microcustaceans, consuming only two species: A. glabra and M. macrocopa having a size of 430 and $1310 \mu \mathrm{m}$ (Tab. 1), respectively, in the polluted environment. By comparison, Tilapia showed a preference for four of the five prey offered (S. vetulus, $M$. macrocopa, M. triserialis and A. glabra). In the eighth week, the final preference analysis of $A$. mexicanum in the contaminated environment indicated that it preferred two species: M. macrocopa and M. triserialis. Tilapia displayed a preference for $M$. macrocopa, M. triserialis, S. vetulus and $H$. incongruens at the end of the study.

In the controls (Fig. 2), an increase in the preferred types of prey was generally observed in the studied species, as was the case in the seventh-week behaviour of $A$. mexicanum control, which manifested a preference for four types (M. macrocopa, S. vetulus, H. incongruens and M. triserialis) of the five prey offered. Its counterpart in the contaminated environment showed a preference for two (M. macrocopa and M. triserialis) of the offered prey species. Regarding the preferences of the fish introduced into the environment, the control showed no preference for any of the five species (M. macrocopa, M. triserialis, A. glabra, $H$. incrongruens and S. vetulus), compared to the contaminated environment, where it preferred A. glabra and $S$. vetulus.

Prey consumption was higher in the control EPA medium than the contaminated lake water on either prey type, M. macrocopa or H. incongruens (Fig. 3). A. mexicanum showed a decrease of 73 and $74 \%$ in the consumption of H. incongruens (Fig. 3) and M. macrocopa (Fig. 3) respectively in the contaminated medium compared to control
(EPA). In the diet of $H$. incongruens (Fig. 3) consumption increased from 25 to 78 individuals during the eight weeks. The axolotl showed significant differences in prey consumption in relation to prey type, prey density and age of the predator $(\mathrm{P}<0.001$, three-way ANOVA) (Tab. 2$)$ on both microcustaceans $M$. macrocopa and $H$. incongruens and in both test media, contaminated and control. Among the prey species offered, A. mexicanum consumed consistently higher numbers of $M$. macrocopa, particularly during the last weeks of the experimental period (Fig. 3). With age, the asymptote of consumption was also shifted to higher values, i.e. 9 to 78 during eight weeks. We observed, in general, greater consumption of microcrustaceans in controls (EPA). The maximum prey consumption of larvae A. mexicanum during the experimental period varied depending on prey taxa and test media (Fig. 3).

\section{DISCUSSION}

In the present study we observed that the feeding behaviour of A. mexicanum was influenced by water quality to a greater extent than that of Tilapia. Water quality in the canals of the lake system is poor since wastewater is used to fill it (Carey and Bryant, 1995; Thomson et al., 1999; Karraker et al., 2008). The adverse effects of this water quality was evident in the functional response tests where prey consumption was about $70 \%$ lower in lake water of lake Xochimilco as compared to the controls. These changes in consumption behaviour may be due to changes in sensory abilities since it is known that pollutants interfere with the smell, and probably therefore with how the feeding behaviour of aquatic organisms (Hara, 1982) A. mexicanum larvae respond to chemical signals. In the prey preference studies we observed that one week old A. mexicanum preferred only A. glabra in contaminated lake water but A. glabra, M. macrocopa and H. incongruens in the controls. A. glabra is preferred mainly because of its small size and slow movements that make

Tab. 2. Three-way ANOVA test on the prey consumption by A. mexicanum offered micro-crustaceans in two media (pollution and control), during the first eight weeks of larval development.

\begin{tabular}{|c|c|c|c|c|c|c|c|c|c|c|}
\hline \multirow[t]{3}{*}{ Source of variation } & \multicolumn{10}{|c|}{ Prey species } \\
\hline & \multicolumn{5}{|c|}{ Heterocypris incongruens } & \multicolumn{5}{|c|}{ Moina macrocopa } \\
\hline & DF & SS & MS & $\mathrm{F}$ & $\mathrm{P}$ & $\mathrm{DF}$ & $\mathrm{SS}$ & MS & $\mathrm{F}$ & $\mathrm{P}$ \\
\hline $\mathrm{A}$ & 1 & 64638 & 64638 & 2662 & $<0.001$ & 1 & 64638 & 64638 & 2662 & $<0.001$ \\
\hline $\mathrm{B}$ & 7 & 142909 & 20415 & 840 & $<0.001$ & 7 & 142909 & 20415 & 840 & $<0.001$ \\
\hline $\mathrm{C}$ & 4 & 883433 & 220858 & 9095 & $<0.001$ & 4 & 883433 & 220858 & 9095 & $<0.001$ \\
\hline Interaction of $\mathrm{A} \times \mathrm{B}$ & 7 & 33278 & 4754 & 195 & $<0.001$ & 7 & 33278 & 4754 & 195 & $<0.001$ \\
\hline Interaction of $\mathrm{A} \times \mathrm{C}$ & 4 & 45545 & 11386 & 468 & $<0.001$ & 4 & 45545 & 11386 & 468 & $<0.001$ \\
\hline Interaction of $\mathrm{B} \times \mathrm{C}$ & 28 & 131006 & 4678 & 192 & $<0.001$ & 28 & 131006 & 4678 & 192 & $<0.001$ \\
\hline Interaction of $\mathrm{A} \times \mathrm{B} \times \mathrm{C}$ & 28 & 27701 & 989 & 40 & $<0.001$ & 28 & 27701 & 989 & 40 & $<0.001$ \\
\hline Error & 240 & 5827 & 24 & & & 240 & 5827 & 24 & & \\
\hline
\end{tabular}

SS, sum of squares; $D F$, degrees of freedom; $M S$, mean square; $F, F$-ratio; $A$, media; $B$, larval age; $C$, prey concentration. 


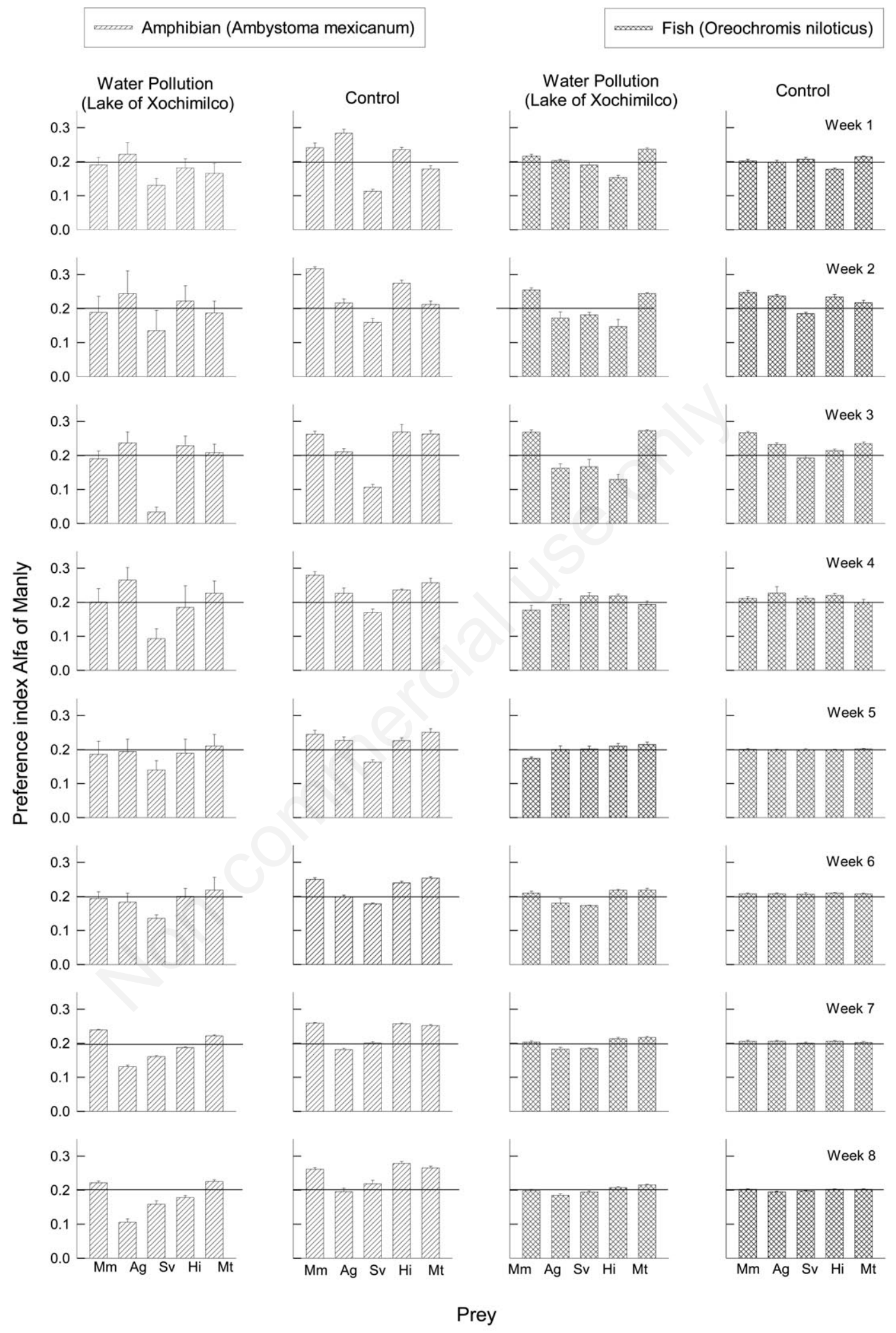

Fig. 2. Food preference ( $<0.2$ Alpha Manly) of Ambystoma mexicanum compared to its competitor - Oreochromis niloticus (Tilapia) introduced into contaminated media (water of lake Xochimilco) and moderately hard water control in the first eight weeks with five species of prey. $\mathrm{Mm}=$ Moina macrocopa; $\mathrm{Ag}=$ Alona glabra; $\mathrm{Sv}=$ Simocephalus vetulus; $\mathrm{Hi}=$ Heterocypris incongruens; $\mathrm{Mt}=$ Macrothrix triserialis. Values are expressed as means \pm standard error based on four replicates. 
Ostracod (Heterocypris incongruens) Water Lake Xochimilco
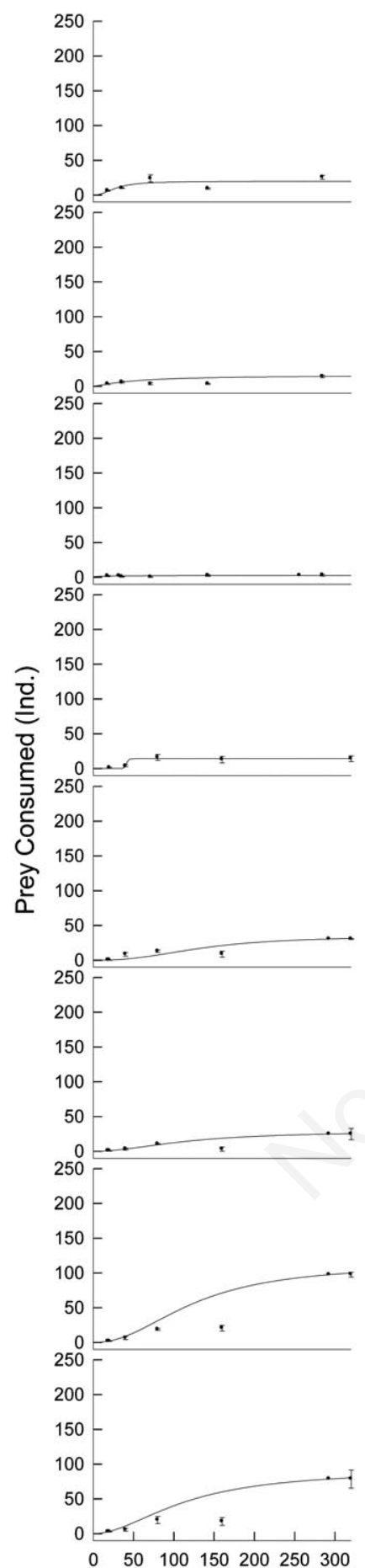

Control
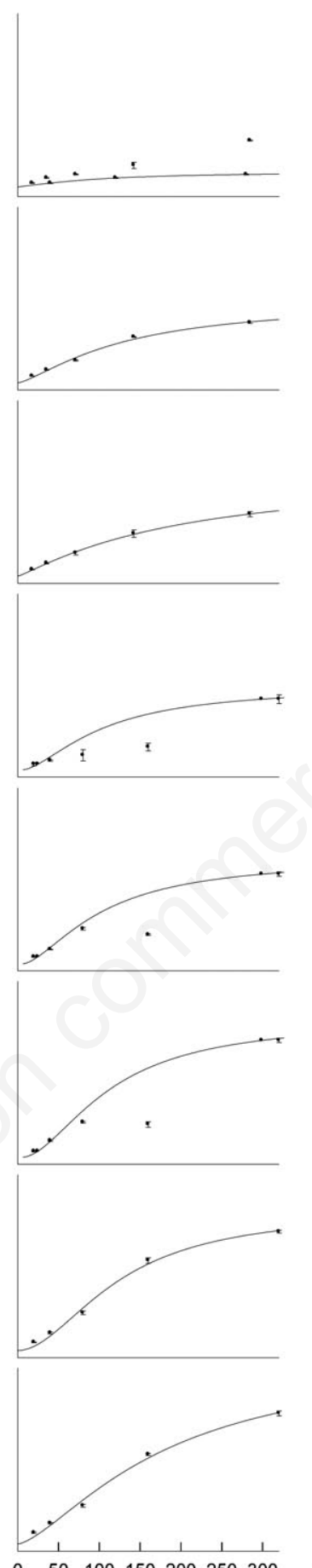

Cladoceran (Moina macrocopa)

Water Lake Xochimilco

Control
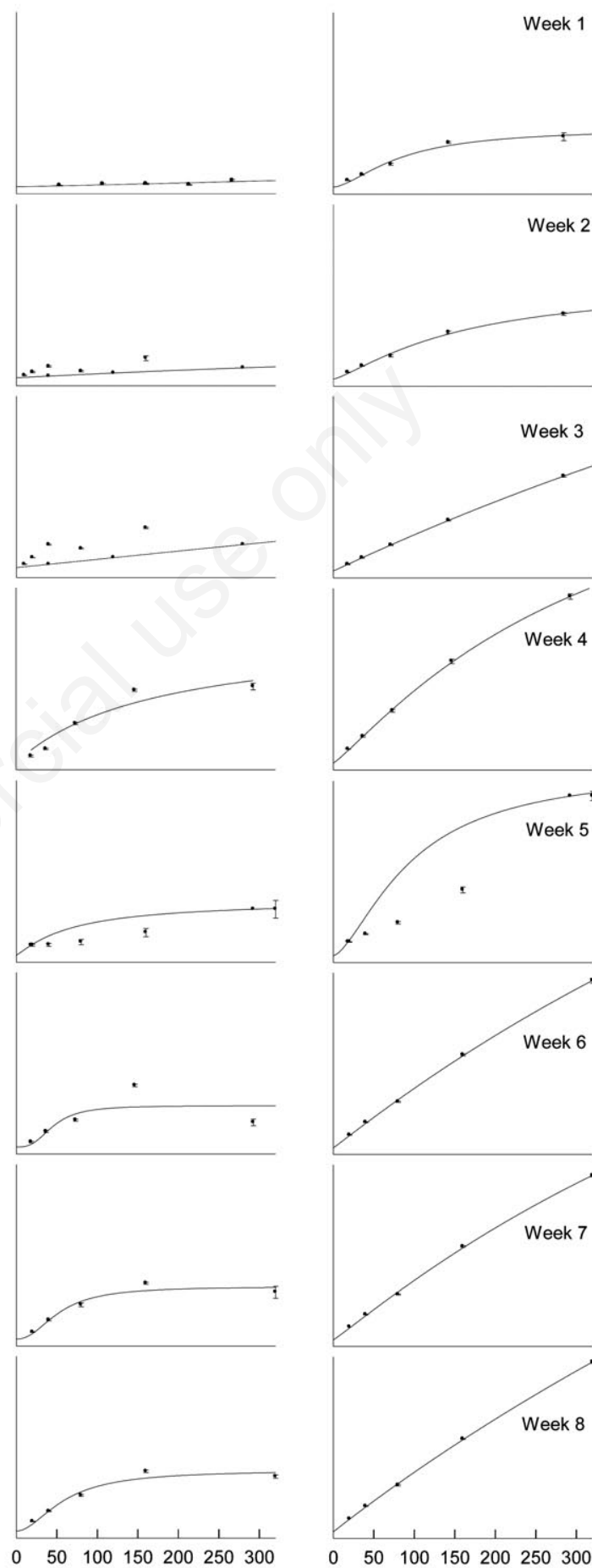

Week 2

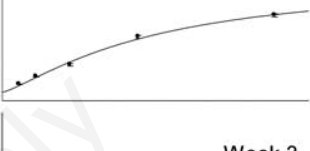

Week 3

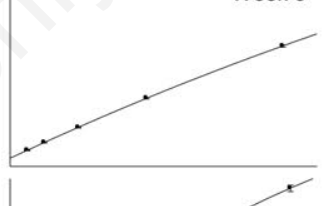

Week 4

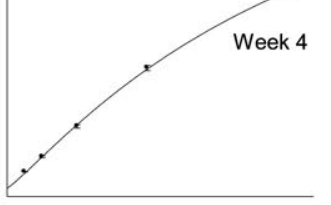

.

Week 5
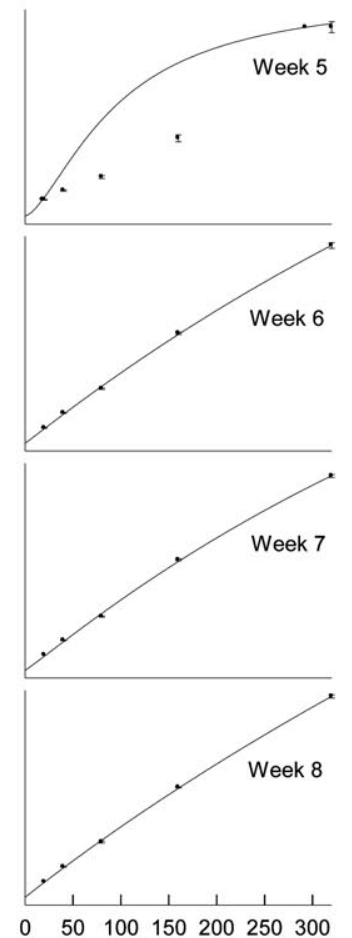

Prey density (ind. total)

Fig. 3. Functional response of A. mexicanum with diet microcrustaceans Heterocypris incongruens (ostracod) and Moina macrocopa (cladoceran) in a polluted environment (water of lake Xochimilco) and moderately hard water control in the first eight weeks. Values are expressed as means \pm standard error based on four replicates. 
it an easy prey. Raimondo et al. (1998) found impaired antipredatory behaviour in bullfrog tadpoles exposed to heavy metals.

The presence of a more resistant invasive species is another major problem in conservation efforts for $A$. mexicanum. The prey preference patterns for $O$. niloticus in lake Xochimilco water was not markedly different than in controls; on the other hand, A. mexicanum showed a preference for a greater variety of prey in uncontaminated water. In preference experiments we found that small amounts of contaminants that do not cause physiological effects may interfere with the behaviour and thereby alter predator-prey and competitive interactions between species (Peterson et al., 2011). Contaminants, especially heavy metals, can change the outcome of competitive interactions (Clements et al., 1992; Landis et al., 1997; Pratt et al., 1997). Our results clearly show that the adverse effects of contaminants on feeding behaviour are greater on the endemic amphibian than on the exotic fish species.

Contaminants also interfere with development. A. mexicanum over eight weeks showed a decrease in consumption both in food preference tests and the functional response experiments. Several studies indicate that consumption rates of predators are significantly lower in contaminated media (Lefcort et al., 1999). Since pollutants also cause increased metabolic costs (Rowe et al., 1998), this combination can be more detrimental for A. mexicanum as it would result in lower growth rates and a lack of nutrients for the necessary metabolism.

There are reports of developmental abnormalities in amphibians when cultured on contaminated waters. For example, Rowe et al. (1998) mentions that bullfrog tadpoles living in contaminated areas have oral deformities resulting in lower grazing capacity. Although we did not observe such deformities, we found the feeding rates to be lower. Nitrate levels in Xochimilco can be expected to be higher as the lake receives partly treated wastewaters. Newly hatched larvae of the salamanders are more susceptible to nitrate (Rouse et al., 1999). It is possible that the reduced feeding rates we observed were due to the development of methemoglobinemia (Hecnar, 1995). Indeed, methemoglobin reduces activity in amphibians, including feeding activity.

Zooplankton populations, the main food of the larvae of A. mexicanum in the early weeks of development, have been strongly affected by the presence of the exotic, introduced fish Oreochromis niloticus because they are susceptible to fish predation. Our observations of high densities of small $(<300 \mu \mathrm{m})$ zooplankton, principally rotifers and a paucity of large $(>1000 \mu \mathrm{m})$ zooplankton such as cladocerans in lake Xochimilco (Nandini et al., 2005) are in accordance with the published literature on fish predation effects on plankton communities (Gliwicz, 2003). While rotifer populations are more re- sistant to these changes (Sarma et al., 2001; RamirezPerez et al., 2004), they are not the preferred prey of axolotls (Chaparro-Herrera et al., 2011). The above is just a small part of all the problems that exist for future reintroduction in lake Xochimilco. Many factors have to be taken into account, such as the effect of each pollutant, turbidity, field studies at the site of the lake, direct effect of the species introduced, etc. Having summed up all the factors affecting larval $A$. mexicanum, it is evident that a management plan is urgently required which has to deal with these factors prior to the reintroduction of this species into lake Xochimilco.

Introduced fish are known for their ability to proliferate rapidly (Denöel et al., 2005; Capps et al., 2009; Purcell et al., 2012), and to reduce zooplankton abundance in lakes and ponds (Sullivan, 2010). As Tilapia grow, their foraging strategies change from visual feeding, focusing almost exclusively on zooplankton (Lu et al., 2009; Lisney and Hawryshyn, 2010; Sabbah et al., 2012). The results obtained in this study indicate that consumption rates of Tilapia are higher than Ambystoma. Shepherd and Mills (1996) estimated that during times of high zooplankton biomass $[>100 \mathrm{mg} / \mathrm{L}$ dry mass (DM)], introduced fish at age 0 consumed more cladocerans. Corroborating the above, our results show higher consumption of large cladocerans such as M. macrocopa and M. triserialis, regardless of water quality. It has been well documented that the overall size structure of zooplankton is smaller in lakes dominated by fish populations (Iglesias et al., 2011). The same is true for lake Xochimilco where small zooplankton dominate in terms of numbers and biomass (EnriquezGarcía et al., 2009). In the case of A. mexicanum, on the other hand, the same results show a disadvantage in consumption in the contaminated medium, a medium originally inhabited by amphibians.

\section{CONCLUSIONS}

There have been many studies on the conservation and reintroduction of endangered species but few have taken into account their ecology or provided in-depth analyses of their habitat. Our work clearly indicates that contamination levels and the presence of high densities of the exotic O. niloticus in lake Xochimilco are among the important factors that can adversely affect $A$. mexicanum populations. Both factors need to be controlled for with the aim of conserving this endemic and endangered amphibian.

\section{ACKNOWLEDGMENTS}

Chaparro-Herrera thanks Posgrado en Ciencias Biológicas (PCBiol) de la Universidad Nacional Autónoma de México (UNAM) for its support in carrying out this project and Consejo Nacional de Ciencia y Tecnología 
(CONACyT) for a doctoral fellowship (CVU 168,672) and UNAM Canada for improving the language of this article. We also thank DGAPA-PAPIIT (IN213413 and IN213513) for financial assistance.

\section{REFERENCES}

Alford AR, Richards JS, 1999. Global amphibian declines: a problem in applied ecology. Annu. Rev. Ecol. Syst. 30:133-165.

Beisner BE, Haydon DT, Cuddington K, 2003. Alternative stable states in ecology. Front. Ecol. Environ. 1:376-382.

Blaustein RA, Bancroftr AB, 2007. Amphibian population declines: evolutionary considerations. BioScience 57:437-444.

Borowitzka MA, Borowitzka LJ, 1988. Micro algal biotechnology. Cambridge University Press, London: 477 pp.

Bridges CM, Semlitsch RD, 2000. Variation in pesticide tolerance of Tadpoles among and within species of Ranidae and patterns of amphibian decline. Conserv. Biol. Ser. 14:14901499.

Capps KA, Turner CB, Booth MT, Lombardozzi DL, McArt SH, Chai D, Hairston Jr NG, 2009. Behavioural responses of the endemic shrimp Halocaridina rubra (Malacostraca: Atyidae) to an introduced fish, Gambusia affinis (Actinopterygii: Poeciliidae) and implications for the trophic structure of Hawaiian anchialine ponds. Pac. Sci. 63:27-37.

Carey C, Bryant CJ, 1995. Possible interrelations among environmental toxicants, amphibian development, and decline of amphibian populations. Environ. Health Persp. 103(Suppl.4):13-17.

Chaparro-Herrera DJ, Nandini S, Sarma SSS, Zambrano L, 2011. Feeding behaviour of larval Ambystoma mexicanum. Amphibia-Reptilia 32:509-517.

Clements WH, Cherry DS, Van Hassel JH, 1992. Assessment of the impact of heavy metals on benthic communities at the Clinch river (Virginia): evaluation of an index of community sensitivity. Can. J. Fish. Aquat. Sci. 49:1686-1694.

Denöel M, Dzurick G, Kalezic G, Kalezic ML, 2005. Effects of widespread fish introductions on paedomorphic newts in Europe. Conserv. Biol. Ser. 19:162-170.

Dominguez-Dominguez O, Nandini S, Sarma SSS, 2002. Larval feeding behaviour of the endangered fish golden bubblebee goodeid, Allotoca dugesi, implications for conservation of an endangered species. Fisheries Manag. Ecol. 9:285-291.

Enriquez-García C, Nandini S, Sarma SSS, 2009. Seasonal dynamics of zooplankton in Lake Huetzalin, Xochimilco (Mexico City, Mexico). Limnologica 39:283-291.

EPA, 1985. Methods of measuring the acute toxicity of effluents to freshwater and marine organisms. US Environment Protection Agency ed, Washington: $266 \mathrm{pp}$. Available from: http://water.epa.gov/scitech/methods/cwa/wet/disk2_index. $\mathrm{cfm}$

Gliwicz ZM, 2003. Between hazards of starvation and risk of predation: the ecology of offshore animals. University of Warsaw ed., Warsaw: 375 pp.

Gliwicz ZM, Wrzosek D, 2008. Predation-mediated coexistence of large- and small-bodied Daphnia at different food levels. Am. Nat 172:358-374.

Hara TJ, 1982. Chemoreception in fishes. Elsevier, Amsterdam: $433 \mathrm{pp}$.

Hecnar SJ, 1995. Acute and chronic toxicity of ammonium ni- trate fertilizer to amphibians from southem Ontario. Environ. Toxicol. Chem. 14:2131-2137.

Higginson AD, Ruxton GD, 2010. Adaptive changes in size and age at metamorphosis can qualitatively vary with predator type and available defenses. Ecology 91:2756-2768.

Hobbs RJ, Huenneke LF, 1992. Disturbance, diversity, and invasion: implications for conservation. Conserv. Biol. Ser. 6:324-337.

Iglesias C, Mazzeo N, Meerhoff M, Lacerot G, Clemente JM, Scasso F, Kruk C, Goyenola G, García-Alonso J, Amsinck SL, Paggi JC, Paggi SJ, Jeppesen E, 2011. High predation is of key importance for dominance of smallbodied zooplankton in warm shallow lakes: evidence from lakes, fish exclosures and surface sediments. Hydrobiologia 667:133-147.

Johnson AF, Valls M, Moranta J, Jenkins SR, Hiddink JG, Hinz H, 2012. Effect of prey abundance and size on the distribution of demersal fishes. Can. J. Fish. Aquat. Sci. 69:191-200.

Karraker NE, Gibbs JP, Vonesh JR, 2008. Impacts of road deicing salt on the demography of vernal pool-breeding amphibians. Ecol. Appl. 18:724-734.

Kiesecker JP, Blaustein AR, 1998. Effects of introduced bullfrogs and smallmouth bass microhabitat use, growth, and survival of native red-legged frogs (Rana aurora). Conserv. Biol. Ser. 12:776-787.

Krebs CJ, 1999. Ecological methodology. Addison Welsey Educational Publ., New York: 620 pp.

Landis WG, Matthews RA, Matthews GB, 1997. Design and analysis of multispecies toxicity tests for pesticide registration. Ecol. Appl. 7:1111-1116.

Lefcort H, Hancock K, Maur K, Rostal D, 1997. The effects of used motor oil and silt on the growth, survival, and the ability to detect predators by tiger salamanders, Ambystoma tigrinum. Arch. Environ. Con. Tox. 32:383-388.

Lefcort H, Thomson SM, Cowles EE, Harowicz HL, Livaudais BM, Roberts W, Ettinger WFE, 1999. Ramifications of predator avoidance: predator and heavy-metal-mediated competition between tadpoles and snails. Ecol. Appl. 9:1477-1489.

Lisney TJ, Hawryshyn CW, 2010. Ocular dimensions and cone photoreceptor topography in adult Nile Tilapia Oreochromis niloticus. Environ. Biol. Fish. 88:369-376.

Lu J, Li J, Furuya Y, Yoshizaki G, Sun H, Endo M, Haga Y, Satoh S, Takeuchi T, 2009. Efficient productivity and lowered nitrogen and phosphorus discharge load from GH-transgenic tilapia (Oreochromis niloticus) under visual satiation feeding. Aquaculture 293:241-247.

Mahaney PA, 1994. Effects of freshwater petroleum contamination on amphibian hatching and metamorphosis. Environ. Toxicol. 13:259-265.

Miller TE, Kerfoot WC, 1987. Redefining indirect effects, p. 3337. In: W.C. Kerfoot and A. Sih (eds.), Predation: direct and indirect impacts on aquatic communities. University of New England Press.

Nandini S, Ramirez-Garcia P, Sarma SSS, 2005. Seasonal variation in the species diversity of planktonic rotifers, in Lake Xochimilco, Mexico. J. Freshwater Ecol. 20:287-294.

Peterson BC, Sellers BW, Fryda NJ, Koupal KD, 2011. Assessment of water quality and response rate of zooplankton in a Nebraska "barrow pit" after rotenone application. Trans. Nebr. Acad. Sci. Affil. Soc. 32:69-74. Available from: 
http://digitalcommons.unl.edu/cgi/viewcontent.cgi?article=1 $004 \&$ context $=$ tnas

Petranka JW, Kats LB, Sih A, 1987. Predator-prey interactions among fish and larval amphibians: use of chemical cues to detect predatory fish. Anim. Behav. 35:420-425.

Pratt JR, Melendez AE, Barreiro R, Bowers NJ, 1997. Predicting the ecological effects of herbicides. Ecol. Appl. 7:1117-1124.

Purcell KM, Ling N, Stockwell CA, 2012. Evaluation of the introduction history and genetic diversity of a serially introduced fish population in New Zealand. Biol. Invasions 14:2057-2065.

Rahel FJ, Olden JD, 2008. Assessing the effects of climate change on aquatic invasive species. Conserv. Biol. Ser. 22:521-533.

Raimondo SM, Rowe CL, Congdon JD, 1998. Exposure to coal ash impacts swimming performance and predator avoidance in larval bullfrogs (Rana catesbeiana). J. Herpetol. 32:289292.

Ramirez-Perez T, Sarma SSS, Nandini S, 2004. Effects of mercury on the life table demography of the rotifer Brachionus calyciflorus pallas (Rotifera). Ecotoxicology 13:535-544.

Rouse JD, Bishop CA, Struger J, 1999. Nitrogen pollution: an assessment of its threat to amphibian survival. Environ. Health Persp. 107:799-803.

Rowe CL, Kinney OM, Nagle RD, Congdon JD, 1998. Elevated maintenance cost in an anuran (Rana catesbeiana) exposed to a mixture of trace elements during the embryonic and early larval periods. Physiol. Zool. 71:27-35.

Sabbah S, Hui J, Hauser FE, Nelson WA, Hawryshyn CW, 2012. Ontogeny in the visual system of Nile tilapia. J. Exp. Biol. 215:2684-2695.

Sarma SSS, Nandini S, Flores JLG, 2001. Effect of methyl parathion on the population growth of the rotifer Brachionus patulus (O. F. Muller) under different algal food (Chlorella vulgaris) densities. Ecotoxicol. Environ. Saf. 48:190-195.

Shepherd WC, Mills EL, 1996. Diel feeding, daily food intake, and Daphnia consumption by age- 0 gizzard shad in Oneida Lake, New York. T. Am. Fish. Soc. 125:411-421.
Sinervo BF, Méndez-de-la-Cruz FR, Miles BD, Heulin B, Bastiaans E, Villagrán-Santa Cruz M, Lara-Resendiz RA, Martínez-Méndez N, Calderón-Espinosa ML, Meza-Lázaro RN, Gadsden H, Avila LJ, Morando M, De la Riva IJ, Victoriano SP, Duarte RCF, Ibargüengoytía N, Aguilar PC, Massot M, Lepetz V, Oksanen TA, Chapple DG, Bauer AM, Branch WR, Clobert J, Sites Jr JW, 2010. Erosion of lizard diversity by climate change and altered thermal niches. Science 328:894-899.

Smith HM, Smith RB, 1971. Synopsis of the herpetofauna of Mexico. I. Analysis of the literature on the Mexican Axolotl. John Johnson Natural History Books ed., Bennington: 245 pp.

Sullivan LJ, 2010. Prey selection of larval and juvenile planktivorous fish in the San Francisco estuary. San Francisco State University ed., San Francisco. Available from: http://wwwcsgc.ucsd.edu/BOOKSTORE/Resources/PP2010/RSF-15Sullivan.pdf

Thomson SM, Cowles EE, Harowicz HL, Livaudais BM, Roberts WE, Ettinger WF, 1999. Ramifications of predator avoidance: predator and heavy-metal-mediated competition between tadpoles and snails Hugh Lefcort. Ecol. Appl. 9:1477-1489.

Townsend CR, 2003. Individual, population, community, and ecosystem consequences of a fish invader in New Zealand streams. Conserv. Biol. Ser. 17:38-47.

Treherne JE, Foster WA, 1981. Group transmission of predator avoidance behaviour in a marine insect: the trafalgar effect. Anim. Behav. 29:911-917.

Wells KD, 2007. The ecology and behaviour of Amphibians. The University of Chicago Press, Chicago: $1085 \mathrm{pp}$.

Werner EE, 1986. Amphibian metamorphosis: growth rate, predation risk, and the optimal size at transformation. Am. Nat. 128:319-341.

Zambrano L, Valiente E, Zanden MJV, 2010. Food web overlap among native axolotl (Ambystoma mexicanum) and two exotic fishes: carp (Cyprinus carpio) and tilapia (Oreochromis niloticus) in Xochimilco, Mexico City. Biol. Invasions 12:3061-3069. 